\title{
In vitro evaluation of the probiotic potential of Lactobacillus isolated from native swine manure
}

\author{
Chiraprapha Tuyarum ${ }^{1}$ (D) Aporn Songsang ${ }^{2}$ (iD) and Monthon Lertworapreecha1 (D) \\ 1. Microbiology Program, Department of Biology, Faculty of Science, Thaksin University, Phatthalung, 93210, Thailand; \\ 2. Faculty of Technology and Community Development, Thaksin University, Phatthalung, 93210, Thailand. \\ Corresponding author: Monthon Lertworapreecha, e-mail: worapreecha@gmail.com \\ Co-authors: CT: jira10jk@gmail.com, AS: asongsang@hotmail.com \\ Received: 22-01-2021, Accepted: 22-03-2021, Published online: 11-05-2021
}

doi: www.doi.org/10.14202/vetworld.2021.1133-1142 How to cite this article: Tuyarum C, Songsang A, Lertworapreecha M (2021) In vitro evaluation of the probiotic potential of Lactobacillus isolated from native swine manure, Veterinary World, 14(5): 1133-1142.

\begin{abstract}
Background and Aim: Using antimicrobials as a feed additive in swine production is prohibited because it is a major cause of the emergence of antimicrobial-resistant bacteria. Probiotics such as Lactobacillus spp. are an attractive alternative to reduce antimicrobial resistance and promote swine growth. This study aimed to evaluate the in vitro probiotic properties of Lactobacillus isolated from indigenous swine manure.

Materials and Methods: A total of 30 fecal samples from healthy individual indigenous pigs were collected and isolated on de Man, Rogosa, and Sharpe agar. The preliminary screen identified candidates with antibacterial activity against six pathogens and $>50 \%$ survival and tolerance to acid $(\mathrm{pH} 3.0)$ and $1 \%$ bile salt. Isolates that passed the initial screen will be tested for other probiotic properties.

Results: Of the 314 isolates from 30 pig manure samples, 17 isolates satisfied all initial conditions for probiotic properties. Each isolate has unique, distinctive properties. Isolates B4, B5, B8, B17, B87, and B144 formed thick biofilms, whereas isolates B5, B8, and 27 adhered well to the intestinal wall and exhibited strong autoaggregation properties. Isolate B4 aggregated with Enterohemorrhagic Escherichia coli and Enteropathogenic E. coli. Tests in pH-adjusted cell-free medium indicated that the antibacterial activity resulted from bacterial acidification rather than bacteriocin formation. Sequence analysis (16S rRNA) revealed 16 of the isolates were Lactobacillus plantarum, and only one isolate was Lactobacillus salivarius.
\end{abstract}

Conclusion: We isolated 17 Lactobacillus from swine manure and demonstrated that their probiotic properties might be useful as a probiotic cocktail for swine feed.

Keywords: Lactobacillus spp., native swine manure, probiotic properties.

\section{Introduction}

Many countries have prohibited antimicrobial feed additives in animal husbandry [1]. Although subtherapeutic antimicrobial doses stimulate livestock growth, their adverse effects encourage pathogenic bacteria in the digestive tract to adapt and become resistant to those antimicrobials. Moreover, resistant bacteria can transfer resistance genes to other bacteria in the environment, rapidly resulting in widespread resistance. The consequence of the ban on antimicrobials in animal feed is an increased incidence of gastrointestinal tract infections. A Danish study indicated that the incidence of Escherichia coli and Lawsonia intracellularis infection in pigs significantly increased in post-weaned pigs after the ban of antimicrobials. Morbidity due to gastrointestinal tract infections in post-weaned pigs also increased $600 \%$ [2].

Copyright: Tuyarum, et al. Open Access. This article is distributed under the terms of the Creative Commons Attribution 4.0 International License (http://creativecommons.org/licenses/ by/4.0/), which permits unrestricted use, distribution, and reproduction in any medium, provided you give appropriate credit to the original author(s) and the source, provide a link to the Creative Commons license, and indicate if changes were made. The Creative Commons Public Domain Dedication waiver (http:// creativecommons.org/publicdomain/zero/1.0/) applies to the data made available in this article, unless otherwise stated.
The use of Lactobacillus spp. to replace antimicrobials has become an attractive alternative [3]. Numerous studies confirm that dietary supplementation with lactobacilli improves growth rate $[4,5]$, enhances the immune response [6], and reduces gastrointestinal tract infections in pigs [7]. Lactobacillus spp. suitable for use as probiotics must have several essential features, including tolerance to acid and bile salt, adherence to intestinal epithelial cells, inhibition of pathogenic bacterial growth, non-pathogenicity, and no antimicrobial-resistance genes [8].

Since there are many Lactobacillus strains, each animal's ideal probiotic strain should be isolated and characterized from the homologous host. Probiotic bacteria isolated from one animal species were best able to colonize the homologous animal intestinal tract and showed the best growth-stimulating performance in the homologous host [9]. Screens of probiotic bacteria usually focus on commercially bred pigs raised in the farm system, and there have been few reports of Lactobacillus isolation from native pigs raised on food scraps (backyard pig). Since backyards pigs are fed on leftovers, they are less likely to be exposed to antimicrobials 
This study aimed to evaluate the in vitro probiotic properties of Lactobacillus isolated from indigenous swine manure.

\section{Materials and Methods}

\section{Ethical approval}

This study required no ethical approval as the collection of samples was from indigenous swine manure. All the other experiments were performed in vitro.

\section{Study period and location}

Samples were collected from February 2019 to April 2019, and the study was performed from February 2019 to January 2020, at the Faculty of Science, Thaksin University (Phatthalung Campus), Thailand.

\section{Isolation of Lactobacillus from pig manure}

A total of 30 individual fecal samples from healthy native pigs were collected immediately after excretion. All fecal specimens were collected in sterile plastic zip bags, immersed in iceboxes, and sent to the laboratory for immediate isolation. Approximately $2 \mathrm{~g}$ of each fecal sample was diluted ten-fold in sterile $0.85 \% \mathrm{NaCl}$, and then $10 \mathrm{~mL}$ of each $10^{-3}-10^{-5}$ dilution was spread directly on de Man, Rogosa, Sharpe (MRS; HiMedia, India) agar supplemented with $0.01 \%(\mathrm{w} / \mathrm{v})$ bromocresol purple. The plates were incubated anaerobically at $37^{\circ} \mathrm{C}$ for $24-48 \mathrm{~h}$, and then at least five colonies surrounded by a yellow zone were selected and purified for further characterization. Colonies of Gram-positive, non-spore-forming bacilli, negative for catalase enzyme, and indole production were preserved at $-80^{\circ} \mathrm{C}$ for further study.

\section{Antimicrobial activity against pathogenic bacteria}

The inhibitory activity was investigated by the agar well diffusion method [10] against Enterohemorrhagic E. coli (EHEC, isolated strain), Enteropathogenic E. coli (EPEC, isolated strain), Staphylococcus aureus (ATCC 25923), Klebsiella pneumoniae (ATCC 700603), Pseudomonas aeruginosa (ATCC 27853), and Salmonella Typhimurium (extended-spectrum beta-lactamases [ESBL]producing strain; isolated strain) [11]. In brief, all the selected bacteria were cultured in MRS broth (HiMedia: India) for $48 \mathrm{~h}$, then cell-free supernatants (CFSs) were collected by centrifugation at $8000 \times g$ for $10 \mathrm{~min}$ and sterilized using a $0.2-\mu \mathrm{M}$ sterile syringe filter membrane (Sartorius, USA). The supernatant was divided into three tubes. There was no need to adjust the $\mathrm{pH}$ in the first tube, and the second and third tubes were adjusted to $\mathrm{pH} 4.5$ and 5.0 with $5 \mathrm{~N} \mathrm{NaOH}$ and a $\mathrm{pH}$ meter (Sartorius, USA). The antimicrobial activity of the CFSs at different $\mathrm{pH}$ was investigated. The pathogenic indicator strain was adjusted to 0.5 McFarland standard $\left(1.5 \times 10^{8} \mathrm{cfu} \mathrm{mL}^{-1}\right)($ Den- $1 \mathrm{~B}$, suspension turbidity detector, BioSan England) in 0.85\% $\mathrm{NaCl}$ before spreading on tryptic soy agar (TSA) (HiMedia, India). Using a 6-mm Cork borer, holes were punched in the TSA plate, and $80-\mu \mathrm{L}$ CFS was applied to each agar well. The TSA plate was incubated at $37^{\circ} \mathrm{C}$ for $24 \mathrm{~h}$, and the inhibitory activity was observed by measuring the clarified zone around each agar well (measured in $\mathrm{mm}$ ).

\section{Acid and bile salt tolerance}

The preparation of the inoculum for acid and bile salt tolerance assays was performed as described by Ehrmann et al. [12]. All isolates were incubated anaerobically in MRS broth at $37^{\circ} \mathrm{C}$ for $48 \mathrm{~h}$, and sub-cultured in MRS broth for $24 \mathrm{~h}$, then adjusted to $0.5 \mathrm{McFarland}$ in phosphate-buffered saline (PBS), $\mathrm{pH}$ 7.4.

For acid tolerance testing, $100 \mu \mathrm{L} \quad(0.5$ McFarland) of each strain in MRS broth was adjusted to $\mathrm{pH} 2.0$ and 3.0 with $1 \mathrm{M} \mathrm{HCl}$ and incubated anaerobically at $37^{\circ} \mathrm{C}$ for 0 and $3 \mathrm{~h}$. Aliquots $(100 \mu \mathrm{L})$ were spread on MRS agar and incubated at $37^{\circ} \mathrm{C}$ for $48 \mathrm{~h}$. Survival was calculated as follows:

Survival percentage $=\left(\mathrm{N}_{1} / \mathrm{N}_{0}\right) \times 100$

$\mathrm{N}_{0}=$ Initial inoculum quantity,

$\mathrm{N}_{1}=$ number of viable bacteria.

For the bile salts tolerance assay, a $100-\mu \mathrm{L}, 0.5$ McFarland aliquot of each strain was treated with $1 \%$ $(\mathrm{w} / \mathrm{v})$ bile salt solution (HiMedia, India) and incubated anaerobically at $37^{\circ} \mathrm{C}$ for 0 and $3 \mathrm{~h}$. The survival rate in $1 \%$ bile salt solution was performed as described for the acid tolerance test.

\section{Biofilm formation assay}

Biofilm formation was assessed in triplicate in 96-well microtiter plates, adapted from a previously described method [13]. Briefly, inoculum strains were cultured in MRS agar for $48 \mathrm{~h}$ and adjusted to 0.5 McFarland standards in $0.85 \% \mathrm{NaCl}$. A $180-\mu \mathrm{L}$ aliquot of MRS broth supplemented with $5 \%(\mathrm{w} / \mathrm{v})$ glucose per well was inoculated with $20-\mu \mathrm{L}$ inoculum, then anaerobically incubated at $37^{\circ} \mathrm{C}$ for $36 \mathrm{~h}$. The MRS broth was discarded from each well, washed twice with $200-\mu \mathrm{L}$ sterile distilled water, and washed twice with $200-\mathrm{mL} 0.85 \% \mathrm{NaCl}$. The plate was dried at room temperature for about $30 \mathrm{~h}$ before staining with $0.05 \%(\mathrm{v} / \mathrm{v})$ crystal violet (HiMedia, India) for $50 \mathrm{~min}$. The staining solution was removed, and each well was washed twice with $200-\mu \mathrm{L}$ distilled water. The plate was dried at room temperature for $30 \mathrm{~min}$, and then $200 \mu \mathrm{L} 95 \%$ ethanol was added and transferred to a new 96-well plate. Optical density was measured at $600 \mathrm{~nm}$. P. aeruginosa (ATCC 27853) and $E$. coli $\mathrm{DH} 5-\alpha$ were used as positive and negative controls for biofilm production.

\section{Hydrophobicity}

The hydrophobicity assay was adapted from a published method [14]. In brief, the isolated strains were cultured in MRS broth for $24 \mathrm{~h}$, and then the cells were collected by centrifugation at $8000 \times g$ for 10 min and washed twice with PBS (pH 7.4). The cell pellet was resuspended and adjusted to $\mathrm{OD}_{600} 0.6$ in PBS (designed as A0), then a 3-mL aliquot was added 
to 1-mL xylene $\left(\mathrm{C}_{6} \mathrm{H}_{4}\left(\mathrm{CH}_{3}\right)_{2}\right)$, shaken vigorously for 2 min using a vortex mixer, and left to stand at room temperature for $15 \mathrm{~min}$ to allow separation of the aqueous phase. The reduction in absorbance was measured by spectrophotometry at $600 \mathrm{~nm}$ (designated A1). The hydrophobicity percentage of each isolate was calculated as follows:

$$
\% \text { hydrophobicity }=\left[\left(\mathrm{A}_{0}-\mathrm{A}_{1}\right) / \mathrm{A}_{0}\right] \times 100 \text {. }
$$

\section{Evaluation of autoaggregation and coaggregation}

Autoaggregation and coaggregation testing were based on a published method of Dias et al. [15]. Briefly, the bacteria were cultured anaerobically in MRS broth at $37^{\circ} \mathrm{C}$ for $48 \mathrm{~h}$, then washed twice with PBS (pH 7.4) and adjusted to $\mathrm{OD}_{600} 0.6$. A 5-mL aliquot was shaken vigorously for 2 min using a vortex mixer and incubated for $4 \mathrm{~h}$ at room temperature. A $10-\mu \mathrm{L}$ aliquot of the upper suspension was gently transferred to a 96-well plate containing $190-\mu \mathrm{L}$ PBS, and the reduction in absorbance was measured at $600 \mathrm{~nm}$. The autoaggregation percentage of each isolate was calculated as follows:

1 - (OD of upper suspension/OD of Total bacterial suspension $) \times 100$.

The coaggregation assay was performed with pathogenic bacteria, S. Typhimurium, EHEC, and EPEC, using an equal volume of each isolated strain and pathogenic strain adjusted to $\mathrm{OD}_{600} 0.6$. Absorbance at $600 \mathrm{~nm}$ was measured again after $4 \mathrm{~h}$ incubation, and the coaggregation percentage was calculated as follows:

$$
\begin{aligned}
& \left.\left[\left\{\left(\mathrm{A}_{\text {pat }}+\mathrm{A}_{\text {probio }}\right) / 2-\mathrm{A}_{\text {mix }}\right\} /\left(\mathrm{A}_{\text {pat }}+\mathrm{A}_{\text {probio }}\right) / 2\right)\right] \times 100 \\
& \mathrm{~A}_{\text {pat }} \text { and } \mathrm{A}_{\text {probio }} \text { represent absorbance of the } \\
& \text { controls } \\
& \mathrm{A}_{\text {mix }} \text { represents the absorbance of the mixed }
\end{aligned}
$$
bacteria.

\section{Adhesion to Caco-2 cells}

The adhesion assay was performed as described by Sh et al. [16]. In brief, Caco-2 human epithelial colorectal adenocarcinoma cells $\left(1.2 \times 10^{5}\right.$ cells $\left.\mathrm{mL}^{-1}\right)$ were cultured in 24-well plates with Dulbecco's modified Eagles' minimal essential medium (DMEM) supplemented with $10 \%(\mathrm{v} / \mathrm{v})$ fetal bovine serum. Cells were incubated at $37^{\circ} \mathrm{C}$ in a $\mathrm{CO}_{2}$ incubator to confluence. The cells were washed twice with PBS (pH 7.4) after adding $1 \mathrm{~mL}$ of the isolated bacteria (0.5 McFarland standards) in serum-free DMEM and incubated at $37^{\circ} \mathrm{C}$ in a $\mathrm{CO}_{2}$ incubator for $90 \mathrm{~min}$. The media was removed, and the wells were washed 3 times with PBS. After washing, $1 \mathrm{~mL}$ of $0.05 \%(\mathrm{v} / \mathrm{v})$ Triton X-100 was added to each well and incubated at room temperature for $10 \mathrm{~min}$. The Triton X-100 was diluted 10 -fold with sterile normal saline, spread onto MRS agar, and incubated anaerobically at $37^{\circ} \mathrm{C}$ for $48 \mathrm{~h}$. Colonies were counted, and the percentage of adhesion ability was calculated as follows:

$\%$ adhesion ability $=($ Number of bacteria attached to cells/total cells number) $\times 100$.
Hemolytic activity and antimicrobial susceptibility testing

One colony of each isolated strain was picked from the MRS agar and re-streaked onto Columbia blood agar ( $5 \%$ human blood), then incubated anaerobically at $37^{\circ} \mathrm{C}$ for $48 \mathrm{~h}$ and observed for hemolysis. All isolates were tested with eight antimicrobial drugs (ampicillin, cephalothin, chloramphenicol, erythromycin, vancomycin, norfloxacin, streptomycin, and tetracycline) (HiMedia), using the disc diffusion technique recommended by the Clinical and Laboratory Standards Institute [17].

\section{Identification of the isolates bacteria by $16 S$ rRNA gene sequencing}

Bacterial DNA extraction was performed using a kit (G-spin Genomic DNA Extraction Kit, iNtRON Biotechnology, Korea). Primers 27F (5Fmersnologynl,m beta-lactam and 1492R (592Rrsnologynl, m beta-lactams were used to amplify the 16S rRNA gene in a thermocycler (MULTIGENE mini, Labnet, USA) in 50- $\mu \mathrm{L}$ platinum TM hot start Polymerase chain reaction (PCR) master mix (Thermo Fisher). Cycling conditions were as follows: Initial activation at $95^{\circ} \mathrm{C}$ for $10 \mathrm{~min} ; 30$ cycles of denaturation at $95^{\circ} \mathrm{C}$ for $1 \mathrm{~min}$, annealing at $50^{\circ} \mathrm{C}$ for $1 \mathrm{~min}$, and extension at $72^{\circ} \mathrm{C}$ for $90 \mathrm{~s}$. The final cycle was $72^{\circ} \mathrm{C}$ for $5 \mathrm{~min}$. The 1466-bp products were analyzed by agarose gel electrophoresis, purified with a kit (NucleoSpin Gel and PCR Clean-up Kit, MachereyNagel, England), and sequenced (Macrogen, Korea). Sequences were aligned using MEGA $\mathrm{X}$ software (www.megasoftware.net) [18] and compared by BLAST to representative sequences in GenBank. The phylogenetic tree was constructed based on the maximum likelihood method.

\section{Statistical analysis}

The results on acid resistance, bile salt resistance, autoaggregation, coaggregation, and hydrophobicity were analyzed by one-way analysis of variance. Biofilm production in test and control groups was analyzed by t-test. All statistical tests were performed with Prism V.5 software (GraphPad Software, San Diego, CA, USA).

\section{Results}

\section{Isolation of Lactobacillus from pig feces}

In this study, a total of 314 isolates of lactic acid bacteria were isolated from 30 samples of individual native pig manure. The preliminary identification showed that all strains were Gram-positive, rod-shaped, non-motile, non-spore-forming, and negative for acid production, catalase, and indole production, a property of Lactobacillus spp.

\section{Antimicrobial activity against pathogenic bacteria}

Of 314 isolates, $288(91.72 \%)$ inhibited the growth of K. pneumoniae, 277 (88.21\%) inhibited the growth of $S$. aureus, $264(84.08 \%)$ inhibited the growth of EHEC, 225 (81.21\%) inhibited the growth of EPEC, $242(77.07 \%)$ inhibited the growth of 
P. aeruginosa, and $212(67.52 \%)$ inhibited the growth of $S$. Typhimurium. We identified 78 isolates that inhibited the growth of all pathogenic strains tested, and these were selected for further characterization. Isolates were selected if they inhibited the growth of 6 pathogenic bacteria (inhibition zone at least $12 \mathrm{~mm}$ ) and exhibited $>50 \%$ survival in $\mathrm{pH} 3.0$ and 1\% bile salts: 17 isolates met these criteria (Table-1). To determine whether the inhibitory effect resulted from acid or bacteriocin formation, we took cell-free media from each isolate, adjusted the $\mathrm{pH}$ to 4.5 and 5.0, and re-tested for inhibition of EHEC, S. aureus, and $S$. Typhimurium again. The results showed that the antibacterial efficacy of all 17 isolates decreased with increased $\mathrm{pH}$, suggesting that the pathogenic bacteria's inhibition was due to the generated acid (Table-2).

\section{Acid and bile salt tolerance}

The 78 isolates that exhibited activities against all pathogenic strains were selected for acid and bile salt tolerance assays. None of the isolates could survive at $\mathrm{pH} 2.0$, but all 78 isolates survived to varying degrees when exposed to $\mathrm{pH} 3.0$. In the $1 \%$ bile salt tolerance test, all 78 isolates survived at various rates. Therefore, to obtain high potential probiotic lactobacilli, isolates that showed $>50 \%$ survival in an environment with $\mathrm{pH} 3.0$ and $1 \%$ bile salt solution were selected for further characterization. We identified only 17 isolates (B1, B3, B4, B5, B8, B10, B11, B16, B17, B21, B27, B87, B88, B93, В126, $\mathrm{B} 144$, and $\mathrm{B} 172$ ) with a survival rate of $>50 \%$ in an environment with $\mathrm{pH} 3.0$ and with $1 \%$ bile salt solution, and all inhibited all six pathogenic bacteria (Table-1).

\section{Biofilm formation}

Only six isolates (B4, B5, B8, B17, B87, and B144) produced more biofilm than the $E$. coli $\mathrm{DH} 5$ - $\alpha$-negative control, with statistical significance. Four of these isolates (B8, B17, B87, and B144) produced more biofilm than $P$. aeruginosa, which was used as a positive control, and two isolates (B144 and B8) produced significantly denser biofilms than P. aeruginosa (Figure-1a).

\section{Autoaggregation, hydrophobicity, and adhesion to Caco- 2 cells}

Only three isolates (B5, B8, and B27) revealed consistent results in autoaggregation, hydrophobicity, and Caco-2 cell adhesion. Isolate B27 exhibited a particularly strong ability to adhere to intestinal epithelial cells, with $88 \%$ hydrophobicity, $78.54 \%$ autoaggregation, and $84.66 \%$ adhesion to Caco-2 cells (Figure-1b). Considering the hydrophobicity results separately, there were seven isolates (B5, B8, B16, B27, B87, and B172) with a hydrophobicity index of $>50 \%$ (Figure-1b). The autoaggregation assay showed clumping of all 17 isolates ranging from 19.08\%$71.63 \%$. Most showed an autoaggregation percentage of $<50 \%$. Only four isolates (B4, B5, B17, and B27) had an autoaggregation value of $>50 \%$, with isolates $\mathrm{B} 27$ and B172 being the highest (Figure-1b). Only seven isolates (B3, B4, B5, B8, B17, B27, and B144) showed $>50 \%$ adhesion to Caco-2 cells (Figure- $1 \mathrm{~b}$ ).

\section{Coaggregation with pathogenic bacteria}

We selected $S$. Typhimurium, EHEC, and EPEC to represent enteric pathogens for the coaggregation assay. All 17 isolates aggregated with EHEC and EPEC more than with $S$. Typhimurium, most with an aggregation percentage of $>50 \%$ with $E$. coli especially. Isolate B4 bound EHEC and EPEC at $71.96 \%$

Table-1: The 17 isolates of lactic acid bacteria that exhibited antibacterial activity and well tolerate to acid and bile salt.

\begin{tabular}{|c|c|c|c|c|c|c|c|c|}
\hline \multirow[t]{2}{*}{ Isolates } & \multicolumn{6}{|c|}{ Inhibition zone $(\mathrm{mm}) *$} & \multirow{2}{*}{$\begin{array}{c}\text { Acid tolerance } \\
(\%)\end{array}$} & \multirow{2}{*}{$\begin{array}{c}\text { Bile salt } \\
\text { tolerance }(\%) \\
1 \% \text { Bile salt }\end{array}$} \\
\hline & EHEC & EPEC & S. aureus & K. pneumoniae & P. aeruginosa $S$. & Typhimurium & & \\
\hline B1 & 30 & 18 & 15 & 19 & 14 & 12 & 88 & 100 \\
\hline B3 & 30 & 22 & 12 & 19 & 23 & 24 & 70.45 & 76 \\
\hline B4 & 25 & 16 & 16 & 16 & 20 & 19 & 100 & 58.90 \\
\hline B5 & 26 & 16 & 18 & 13 & 22 & 21 & 89.65 & 60.56 \\
\hline B8 & 25 & 17 & 18 & 18 & 19 & 22 & 100 & 100 \\
\hline B10 & 25 & 15 & 12 & 18 & 20 & 18 & 100 & 60 \\
\hline B11 & 25 & 18 & 15 & 17 & 21 & 18 & 53.85 & 100 \\
\hline B16 & 26 & 16 & 16 & 18 & 24 & 17 & 81.81 & 80 \\
\hline B17 & 30 & 18 & 16 & 18 & 23 & 19 & 100 & 100 \\
\hline B21 & 32 & 20 & 13 & 25 & 24 & 24 & 100 & 58.62 \\
\hline B27 & 32 & 18 & 17 & 17 & 23 & 17 & 100 & 80.64 \\
\hline B87 & 14 & 14 & 15 & 16 & 15 & 14 & 67.33 & 100 \\
\hline B88 & 14 & 16 & 21 & 20 & 14 & 12 & 100 & 100 \\
\hline B93 & 15 & 17 & 16 & 20 & 14 & 15 & 100 & 86.45 \\
\hline B126 & 20 & 17 & 20 & 21 & 16 & 22 & 100 & 80.64 \\
\hline B144 & 16 & 15 & 20 & 13 & 13 & 17 & 80 & 61 \\
\hline B172 & 23 & 20 & 30 & 15 & 21 & 24 & 80 & 71 \\
\hline
\end{tabular}

*Cork borer: $6 \mathrm{~mm}$ in diameter. EHEC and EPEC: (isolated strain), S. aureus (ATCC 259), K. pneumoniae (ATCC 700603), P. aeruginosa (ATCC 27853), S. Typhimurium (isolated strain). EHEC=Enterohemorrhagic Escherichia coli, $\mathrm{EPEC}=$ Enteropathogenic Escherichia coli, S. aureus=Staphylococcus aureus, $\mathrm{K}$. pneumonia=Klebsiella pneumonia, $P$. aeruginosa $=P$ seudomonas aeruginosa, $S$. Typhimurium $=$ Salmonella Typhimurium 
Table-2: The antimicrobial activity of supernatants under various $\mathrm{pH}$ values.

\begin{tabular}{|c|c|c|c|c|c|c|c|c|c|c|}
\hline \multirow[t]{3}{*}{ Isolate } & \multirow{3}{*}{$\begin{array}{c}\text { pH of } \\
\text { supernatant }\end{array}$} & \multirow{2}{*}{\multicolumn{3}{|c|}{$\begin{array}{c}\text { EHEC } \\
\text { Clear zone }(\mathrm{mm})^{*}\end{array}$}} & \multirow{2}{*}{\multicolumn{3}{|c|}{$\begin{array}{c}\text { S. aureus } \\
\text { Clear zone }(\mathbf{m m})\end{array}$}} & \multirow{2}{*}{\multicolumn{3}{|c|}{$\begin{array}{l}\text { S. Typhimurium } \\
\text { Clear zone (mm) }\end{array}$}} \\
\hline & & & & & & & & & & \\
\hline & & Original & pH 4.5 & pH 5.0 & Original & pH 4.5 & pH 5.0 & Original & pH 4.5 & pH 5.0 \\
\hline$\overline{B 1}$ & 3.58 & 30 & 27 & 20 & 15 & 9 & 7 & 12 & 7 & 6 \\
\hline B3 & 3.38 & 30 & 27 & 22 & 12 & 8 & 6 & 24 & 13 & 7 \\
\hline B4 & 3.77 & 25 & 22 & 18 & 16 & 8 & 6 & 19 & 14 & 6 \\
\hline B5 & 3.67 & 26 & 21 & 19 & 18 & 9 & 6 & 21 & 17 & 9 \\
\hline B8 & 3.76 & 25 & 19 & 16 & 18 & 10 & 7 & 22 & 15 & 9 \\
\hline B10 & 3.88 & 25 & 19 & 14 & 12 & 7 & 6 & 18 & 9 & 7 \\
\hline B11 & 3.73 & 25 & 20 & 14 & 15 & 8 & 6 & 18 & 10 & 7 \\
\hline B16 & 3.76 & 26 & 20 & 13 & 16 & 8 & 6 & 17 & 10 & 6 \\
\hline B17 & 3.45 & 30 & 24 & 14 & 16 & 8 & 6 & 19 & 11 & 7 \\
\hline B21 & 3.44 & 32 & 24 & 13 & 13 & 7 & 6 & 24 & 14 & 8 \\
\hline B27 & 3.56 & 32 & 24 & 15 & 17 & 8 & 6 & 17 & 10 & 8 \\
\hline B87 & 4.01 & 14 & 9 & 7 & 15 & 8 & 6 & 14 & 7 & 7 \\
\hline B88 & 3.98 & 14 & 8 & 6 & 21 & 9 & 7 & 12 & 7 & 6 \\
\hline B93 & 3.85 & 15 & 8 & 6 & 16 & 8 & 6 & 15 & 6 & 6 \\
\hline B126 & 3.78 & 20 & 16 & 9 & 20 & 10 & 7 & 22 & 14 & 8 \\
\hline B144 & 3.93 & 16 & 10 & 7 & 20 & 10 & 7 & 17 & 6 & 6 \\
\hline B172 & 3.77 & 23 & 18 & 8 & 30 & 16 & 9 & 24 & 16 & 9 \\
\hline
\end{tabular}

*Cork borer: $6 \mathrm{~mm}$ in diameter. EHEC: (isolated strain), S. aureus (ATCC 259), S. Typhimurium (isolated strain).

EHEC=Enterohemorrhagic Escherichia coli, EPEC=Enteropathogenic Escherichia coli, S. aureus=Staphylococcus aureus, S. Typhimurium=Salmonella Typhimurium

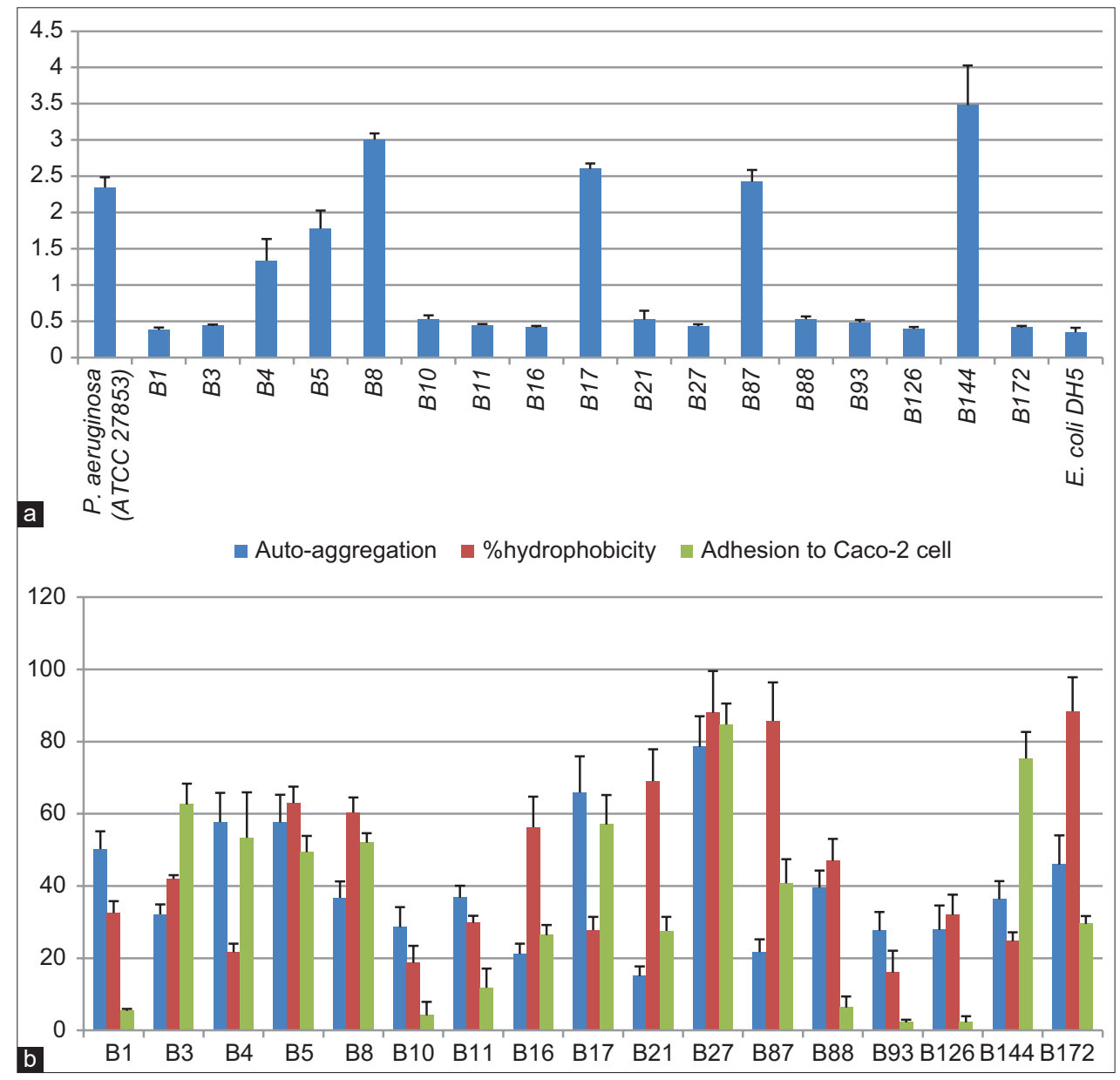

Figure-1: (a) Graph showing the biofilm production of the 17 isolates. The obtained value was shown from the average values of the three repeated experiment \pm standard deviation (SD). (b) Graph showing the percentage of auto-aggregation, hydrophobicity, and adhesion to Caco-2 cell. The obtained value was demonstrated from the average values of the three repeated experiment \pm SD.

and $91.44 \%$, respectively (Figure-2). However, only isolate B17 aggregated with $S$. Typhimurium at an efficiency of $>50 \%$ (Figure- 2 ).

\section{Antimicrobial susceptibility and hemolysis}

Antimicrobial susceptibility testing showed that all isolates were susceptible to cephalothin, 


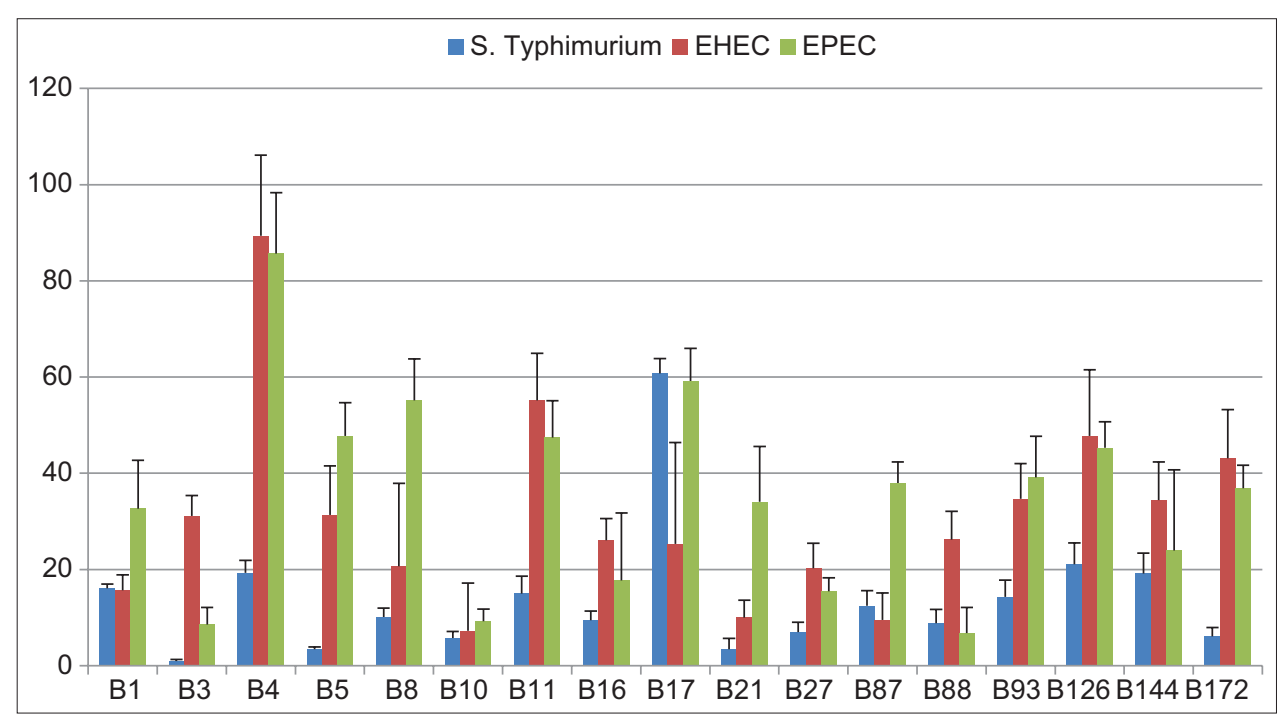

Figure-2: Graph showing the co-aggregation of the 17 isolates together with Salmonella Typhimurium, Enterohemorrhagic Escherichia coli, and Enteropathogenic Escherichia coli. The obtained value was demonstrated from the average values of the three repeated experiment \pm standard deviation.

chloramphenicol, erythromycin, streptomycin, and ampicillin, but only one isolate (B27, 5.88\%) was resistant to tetracycline. It was notable that only $17.64 \%$ (B1, B3, and B5) were sensitive to vancomycin, and $11.76 \%$ (B1 and B5) were sensitive to norfloxacin. Three isolates (B1, B3, and B10) exhibited partial or incomplete lysis of red blood cells $(\alpha$-hemolysis) with a 1-mm partial or slightly green clear zone around the bacterial colonies. In contrast, the remaining 14 isolates (B4, B5, B8, B17, B11, B16, B21, B27, B87, B88, B93, B126, B144, and B172) exhibited non-hemolysis (g-hemolysis) (Table-3).

\section{Identification by $16 S$ rRNA gene sequencing}

All 17 isolates were characterized by $16 S r R N A$ gene sequencing, and a phylogenetic tree was constructed with the nucleotide sequences retrieved from GenBank. The analysis showed 16 of the isolates were Lactobacillus plantarum, with identities ranging from $98.69 \%$ to $100 \%$, and one isolate (B27) shared $99.35 \%$ identity with Lactobacillus salivarius. The GenBank Accession numbers for the $16 S$ rRNA gene sequence of the 17 isolates are MW165836MW165850 (Table-2 and Figure-3).

\section{Discussion}

In this study, 314 isolates of Lactobacillus were isolated from the manure of 30 native pigs to evaluate their probiotic potential. Initially, we selected 78 isolates of lactic acid bacteria that could inhibit all six pathogenic bacteria: E. coli (EPEC and EHEC), S. aureus, $K$. pneumoniae, $P$. aeruginosa, and $S$. Typhimurium (ESBL-producing strain). These bacteria are a significant problem in the health of pigs and may affect human health $[19,20]$. This study shows that bacteria isolated from healthy native pigs are highly effective in inhibiting pathogenic bacteria. The previous study found that Lactobacillus isolated from commercial pigs, native pigs, and wild boars are highly efficient inhibitors of some pathogenic bacteria [21]. There are disadvantages to isolating Lactobacillus from commercially farmed pigs because they are typically given probiotic Lactobacillus in their feed, making it unlikely that new strains will be identified in these populations.

Antibacterial efficacy decreased when the $\mathrm{pH}$ of the CFS was neutralized, indicating that the ability to inhibit pathogens is mostly a result of acid production. This study is consistent with the previous studies showing that Lactobacillus can inhibit Grampositive and Gram-negative pathogens, especially $E$. coli and $S$. aureus, but are less effective against $S$. Typhimurium, which is more resistant to acids than other enteric pathogens [22,23].

The previous study isolated Lactobacillus from farm pig manure and small intestines obtained in slaughterhouses and showed these strains are less tolerant of acids and bile salts than the isolates obtained in our study [24]. This difference indicates the importance of feeding with kitchen leftovers; backyard native pigs eat regularly, requiring digestion with more acid, and bile salts. The acid and bile salt-resistant bacteria therefore survive and can be more frequently detected in native backyard pigs. Backyard pigs also have a higher chance of exposure to pathogens. These conditions create more opportunities to find a group of lactobacilli that can inhibit pathogenic bacteria.

Acid and salt resistances are essential qualities that make certain probiotic bacteria survive extreme conditions and colonize the digestive tract. We tested the isolates with $1 \%$ bile salt, a higher concentration than is found in the intestines of pigs [22,25]. We found 17 isolates that exhibited $>50 \%$ survival under these conditions. Nevertheless, none survived at $\mathrm{pH}$ 2.0. Therefore, we adjusted to $\mathrm{pH} 3.0$, the stomach $\mathrm{pH}$ range of pigs [26-28], and found $>50 \%$ survival. Acid 
Table-3: Antimicrobial susceptibility testing, hemolysis assay, and identification.

\begin{tabular}{|c|c|c|c|c|c|c|c|c|c|c|c|}
\hline \multirow[t]{2}{*}{ Isolate code } & \multicolumn{8}{|c|}{ Antimicrobial susceptibility testing } & \multirow[t]{2}{*}{ Hemolysis type } & \multirow{2}{*}{\multicolumn{2}{|c|}{$\begin{array}{c}\text { Identification (\% identity)* } \\
\text { Accession No. }\end{array}$}} \\
\hline & CEP & CHL & ERY & STR & AMP & TET & NOR & VAN & & & \\
\hline $\mathrm{B} 1$ & $\mathrm{~S}$ & $\mathrm{~S}$ & $\mathrm{~S}$ & $\mathrm{~S}$ & $\mathrm{~S}$ & $\mathrm{~S}$ & $\mathrm{~S}$ & $\mathrm{~S}$ & $\alpha$ & $\begin{array}{l}\text { L. plantarum } \\
\text { MW165836 }\end{array}$ & $(100)$ \\
\hline B3 & $\mathrm{S}$ & $\mathrm{S}$ & $\mathrm{S}$ & $\mathrm{S}$ & $\mathrm{S}$ & $\mathrm{S}$ & $\mathrm{R}$ & $\mathrm{S}$ & $\alpha$ & $\begin{array}{l}\text { L. plantarum } \\
\text { MW165837 }\end{array}$ & $(99.74)$ \\
\hline B4 & $\mathrm{S}$ & $\mathrm{S}$ & $\mathrm{S}$ & $\mathrm{S}$ & $\mathrm{S}$ & $\mathrm{S}$ & $\mathrm{R}$ & $\mathrm{R}$ & $\gamma$ & $\begin{array}{l}\text { L. plantarum } \\
\text { MW165838 }\end{array}$ & $(99.74)$ \\
\hline B5 & $\mathrm{S}$ & $\mathrm{S}$ & $\mathrm{S}$ & $\mathrm{S}$ & $\mathrm{S}$ & $\mathrm{S}$ & $\mathrm{S}$ & $\mathrm{S}$ & $\gamma$ & $\begin{array}{l}\text { L. plantarum } \\
\text { MW165839 }\end{array}$ & $(99.67)$ \\
\hline B8 & $\mathrm{S}$ & $\mathrm{S}$ & $\mathrm{S}$ & $\mathrm{S}$ & $\mathrm{S}$ & $\mathrm{S}$ & $\mathrm{R}$ & $\mathrm{R}$ & $\gamma$ & $\begin{array}{l}\text { L. plantarum } \\
\text { MW165840 }\end{array}$ & $(98.67)$ \\
\hline B10 & $\mathrm{S}$ & $\mathrm{S}$ & $\mathrm{S}$ & $\mathrm{S}$ & $\mathrm{S}$ & $\mathrm{S}$ & $\mathrm{R}$ & $\mathrm{R}$ & $\alpha$ & $\begin{array}{l}\text { L. plantarum } \\
\text { MW165841 }\end{array}$ & $(99.60)$ \\
\hline B11 & $\mathrm{S}$ & $\mathrm{S}$ & $\mathrm{S}$ & $\mathrm{S}$ & $\mathrm{S}$ & $S$ & $\mathrm{R}$ & $\mathrm{R}$ & $\gamma$ & $\begin{array}{l}\text { L. plantarum } \\
\text { MW165842 }\end{array}$ & $(99.54)$ \\
\hline B16 & $\mathrm{S}$ & $\mathrm{S}$ & $\mathrm{S}$ & $\mathrm{S}$ & $\mathrm{S}$ & $\mathrm{S}$ & $\mathrm{R}$ & $\mathrm{R}$ & $\gamma$ & $\begin{array}{l}\text { L. plantarum } \\
\text { MW165843 }\end{array}$ & $(100)$ \\
\hline B17 & $\mathrm{S}$ & $\mathrm{S}$ & $\mathrm{S}$ & $\mathrm{S}$ & $\mathrm{S}$ & $\mathrm{S}$ & $\mathrm{R}$ & $\mathrm{R}$ & $\gamma$ & $\begin{array}{l}\text { L. plantarum } \\
\text { MW165844 }\end{array}$ & $(99.54)$ \\
\hline B21 & $S$ & S & $\mathrm{S}$ & $\mathrm{S}$ & $\mathrm{S}$ & $S$ & $\mathrm{R}$ & $\mathrm{R}$ & $\gamma$ & $\begin{array}{l}\text { L. plantarum } \\
\text { MW165845 }\end{array}$ & $(99.30)$ \\
\hline B27 & $\mathrm{S}$ & $S$ & $\mathrm{~S}$ & $\mathrm{~S}$ & $\mathrm{~S}$ & $\mathrm{R}$ & $\mathrm{R}$ & $\mathrm{R}$ & $\gamma$ & $\begin{array}{l}\text { L. salivarius } \\
\text { MW165846 }\end{array}$ & $(99.35)$ \\
\hline B87 & $S$ & S & $\mathrm{S}$ & $\mathrm{S}$ & $\mathrm{S}$ & S & $\mathrm{R}$ & $\mathrm{R}$ & $\gamma$ & $\begin{array}{l}\text { L. plantarum } \\
\text { MW165847 }\end{array}$ & $(99.67)$ \\
\hline B88 & $S$ & $S$ & $\mathrm{~S}$ & $\mathrm{~S}$ & $\mathrm{~S}$ & $S$ & $\mathrm{R}$ & $\mathrm{R}$ & $\gamma$ & $\begin{array}{l}\text { L. plantarum } \\
\text { MW165848 }\end{array}$ & $(99.21)$ \\
\hline B93 & $S$ & $S$ & $\mathrm{~S}$ & $\mathrm{~S}$ & $\mathrm{~S}$ & $\mathrm{~S}$ & $\mathrm{R}$ & $\mathrm{R}$ & $\gamma$ & $\begin{array}{l}\text { L. plantarum } \\
\text { MW165849 }\end{array}$ & $(99.21)$ \\
\hline B126 & $\mathrm{S}$ & $\mathrm{S}$ & $\mathrm{S}$ & $\mathrm{S}$ & $\mathrm{S}$ & $\mathrm{S}$ & $\mathrm{R}$ & $\mathrm{R}$ & $\gamma$ & $\begin{array}{l}\text { L. plantarum } \\
\text { MW165851 }\end{array}$ & $(99.53)$ \\
\hline B144 & $\mathrm{S}$ & $\mathrm{S}$ & $\mathrm{S}$ & $\mathrm{S}$ & $\mathrm{S}$ & $\mathrm{S}$ & $\mathrm{R}$ & $\mathrm{R}$ & $\gamma$ & $\begin{array}{l}\text { L. plantarum } \\
\text { MW165852 }\end{array}$ & $(99.00)$ \\
\hline B172 & $\mathrm{S}$ & $S$ & $\mathrm{~S}$ & $\mathrm{~S}$ & $\mathrm{~S}$ & $S$ & $\mathrm{R}$ & $\mathrm{R}$ & $\gamma$ & $\begin{array}{l}\text { L. plantarum } \\
\text { MW165850 }\end{array}$ & $(99.27)$ \\
\hline
\end{tabular}

$\mathrm{CEP}=$ Cephalothin, $\mathrm{CHL}=$ Chloramphenicol, $\mathrm{ERY}=$ Erythromycin, $\mathrm{STR}=$ Streptomycin, $\mathrm{AMP}=\mathrm{Ampicillin}, \mathrm{VAN}=\mathrm{Vancomycin}$, $\mathrm{NOR}=$ Norfloxacin, TET=Tetracycline. R=Resistant (zone diameter, $\leq 12.4 \mathrm{~mm}$ ) S=Susceptible (zone diameter, $\geq 17.5$ ). Erythromycin results based on $\mathrm{R} \leq 13 \mathrm{~mm} ; \mathrm{S} \geq 23 \mathrm{~mm}$. Gentamycin results based on $\mathrm{R} \leq 6 \mathrm{~mm} ; \mathrm{S} \geq 10 \mathrm{~mm}$. Vancomycin results based on $\mathrm{R} \leq 12 \mathrm{~mm} ; \mathrm{S} \geq 13 \mathrm{~mm}$. *All Lactobacillus plantarum were blast against Lactobacillus plantarum NR_042254.1, Lactobacillus salivarius was blast against Lactobacillus salivarius NR_028725.2

tolerance is driven by the F0F1-ATPase mechanism, which is a multi-unit enzyme consisting of catalysts (F1) a, b, g, d, and e for ATP hydrolysis, and the integral membrane (F0) a, b, and c subunits, which act as channels for proton transport [29]. These mechanisms mediate bacterial respiration through proton transport, suggesting that F0F1-ATPase can increase the cell's pH under low $\mathrm{pH}$ conditions by regulating gene expression. In contrast, bile salt tolerance results from bile efflux and bile hydrolysis [30]. Isolates that can withstand such conditions may possess more effective enzymes.

Assays to identify the ability of bacteria to colonize the gastrointestinal tract efficiently include autoaggregation, hydrophobicity, and adhesion to epithelium cells (Caco-2). We employed all three methods to identify isolates with concordant properties. Only three isolates (B5, B8, and B27) exhibited consistent results between the three assays. Coaggregation between the same or different bacterial strains is essential to biofilm formation [31]. However, only isolates B5 and B8 exhibited in vitro adhesion properties and produced biofilm polysaccharides at high levels.
In contrast, isolate B27 showed strong evidence of adhering to intestinal epithelial cells but expressed low levels of biofilm polysaccharides, indicating that this is not the only mechanism involved in biofilm formation. A recent study suggested that L. plantarum produces a surface protein that plays an important role in adherence to the intestinal epithelium. Sodium dodecyl sulfate and mass spectrometry analyses indicated that the surface protein is $100 \%$ homologous to glyceraldehyde-3-phosphate dehydrogenase (GAPDH). Moreover, blocking of GAPDH by anti-GAPDH significantly decreased adherence to intestinal epithelial cells [32]. Likewise, L. sarivarius expresses an S-layer choline-binding protein $\mathrm{A}(\mathrm{CbpA})$ involved in adherence to the human colorectal adenocarcinoma cell line HT-29. Blockade or deletion of CbpA significantly decreased the ability of L. salivarius to adhere to epithelial cells [33]. These alternative models of adhesion may account for the fact that isolate B27 produces low levels of biofilm polysaccharides but can efficiently adhere to the intestinal wall cells. 


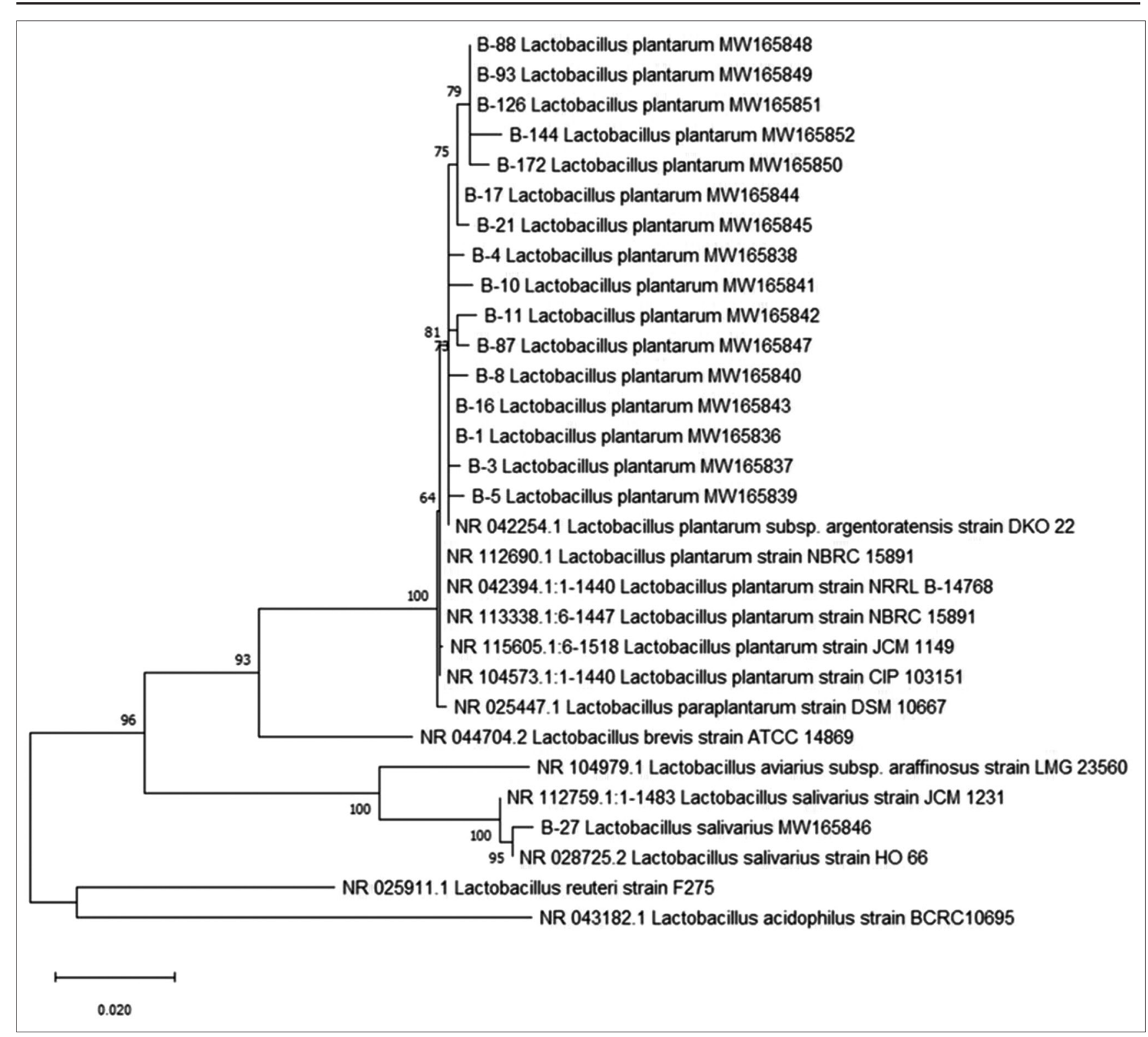

Figure-3: The relationship of Lactobacillus analyzes results and constructs a phylogenetic tree with the MEGA X program by the maximum likelihood method (1000 bootstrap).

Antimicrobial resistance and red blood cell hemolysis are common considerations for screening probiotic bacteria properties. In this study, most isolates were sensitive to all antimicrobial agents, and only one isolate (B27) was resistant to tetracycline. However, we found that most Lactobacillus isolates were resistant to vancomycin and norfloxacin, and only three (B1, B3, and B5) were susceptible to vancomycin, and two (B1, B5) were susceptible to norfloxacin. Vancomycin resistance is not uncommon in Lactobacillus. It is well-known that the terminal D-alanyl-D-alanine residue in the pentapeptide crosslink of several Lactobacillus species is substituted with D-alanyl-D-lactate, to which vancomycin binds with 1000-fold lower affinity [34]. Substitution of D-alanylD-alanine with D-alanyl-D-lactate is mediated by Ddl ligase, an essential enzyme in Lactobacillus peptidoglycan synthesis. Heterologous expression of Ddl ligase in L. plantarum reportedly increases sensitivity to vancomycin [35]. The lactobacilli are also naturally resistant to quinolones (ciprofloxacin, norfloxacin, and nalidixic acid) through an unknown resistance mechanism; however, we cannot explain why isolates B1 and B5 are sensitive to norfloxacin. This study found that only $5 \%$ of Lactobacillus was resistant to tetracycline, in contrast to the previous studies that showed $80 \%$ of the Lactobacillus isolated from commercial farm piglets was resistant to tetracycline [36]. Lactobacillus strains isolated from weaning commercial farm piglets are more frequently resistant to other antimicrobial drugs, suggesting that researchers have a better chance of isolating antimicrobial-susceptible Lactobacillus from native backyard pigs. In addition to hemolysis, almost all isolates exhibited $\gamma$, hemolysis (except isolates B1, B3, and B10), indicating that most of them are relatively safe to use as animal probiotics. Although the probiotic bacteria must be safe and have zero risks, it is difficult to find an 
entirely safe bacterium. Some Lactobacillus species, Leuconostoc, and Pediococcus may show incomplete or partial hemolysis ( $\gamma$-hemolysis) [37,38].

A preliminary classification by $16 \mathrm{~s} r R A$ gene analysis found that $L$. plantarum was the most common isolate, and B27 was identified as L. salivarius, but this does not mean that there is no bacterial diversity in native pigs. Our sequential screening process may have enriched for L. Plantarum. The prevalence of Lactobacillus species varies depending on location in the intestinal tract, age, health status, and diet. L. plantarum and L. fermentum are prevalent in swine manure [39-41]. It may be necessary to understand that the $16 S$ rRNA gene nucleotide sequence may not distinguish all Lactobacillus species because this gene is highly conserved, especially in L. plantarum, $L$. paraplantarum, and L. pentosus. Differentiating these species may require additional techniques, including the PCR-ARDA and specific gene amplification [42]. Although most isolates are L. plantarum, each represented a different strain according to their other characteristics. We thus cannot conclude that they are all L. plantarum.

\section{Conclusion}

An in vitro screen of the probiotic properties of Lactobacillus isolated from pig manure yielded 17 strains from a total of 314 isolates that exhibited favorable probiotic and safety characteristics. Sixteen of these isolates were primarily identified as L. plantarum, and one isolate was identified as L. salivarius. Each isolate has different probiotic strengths and weaknesses. Therefore, their development and application as a novel swine feed supplement will require in vivo investigations to optimize the ideal probiotic cocktail.

\section{Authors' Contributions}

ML: Designed, planned, and supervised the study. CT: Performed all the experiments and collected the data. CT, AS, and ML: Analyzed the results. CT wrote the manuscript. ML and AS edited and finalized the manuscript. All authors read and approved the final manuscript

\section{Acknowledgments}

This study was supported by Thailand Government Endowment Fund 2019, Research and Development Institute (Grant: Code_Ro1-256272956), Thaksin University, Thailand. We would like to thanks Graduated School, Thaksin University, for supporting funds for graduate students. Special thanks to the Department of Biology, Faculty of Thaksin University, for the generosity and laboratory and research tools.

\section{Competing Interests}

The authors declare that they have no competing interests.

\section{Publisher's Note}

Veterinary World remains neutral with regard to jurisdictional claims in published institutional affiliation.

\section{References}

1. Landers, T.F., Cohen, B., Wittum, T.E. and Larson, E.L. (2012) A review of antibiotic use in food animals: Perspective, policy, and potential. Public Health Rep., 127(1): 4-22.

2. Casewell, M., Friis, C., Marco, E., McMullin, P. and Phillips, I. (2003) The European ban on growth-promoting antibiotics and emerging consequences for human and animal health. J. Antimicrob. Chemother., 52(2): 159-161.

3. Liao, S.F.F. and Nyachoti, M. (2017) Using probiotics to improve swine gut health and nutrient utilization. Anim. Nutr., 3(4): 331-343

4. Yu, H.F., Wang, A.N., Li, X.J. and Qiao, S.Y. (2008) Effect of viable Lactobacillus fermentum on the growth performance, nutrient digestibility and immunity of weaned pigs. J. Anim. Feed Sci., 17(1): 61-69.

5. Saleh, A.A., Gálik, B., Arpášová, H., Capcarová, M., Kalafová, A., Šimko, M., Juráček, M., Rolinec, M., Bíro, D. and Abudabos, A.M., (2017) Synergistic effect of feeding Aspergillus awamori and lactic acid bacteria on performance, egg traits, egg yolk cholesterol and fatty acid profile in laying hens. Ital. J. Anim. Sci., 16(1): 132-139.

6. Li, Y.H., Hou, S.L., Peng, W., Lin, Q., Chen, F.M., Yang, L.Y., Li, F.N. and Huang, X.G. (2019) Oral administration of Lactobacillus delbrueckii during the suckling phase improves antioxidant activities and immune responses after the weaning event in a piglet model. Oxid. Med. Cell Longev., 3(1): 6919803.

7. Yang, G.Y., Yu, J., Su, J.H., Jiao, L.G., Liu, X. and Zhu, Y.H. (2017) Oral administration of Lactobacillus rhamnosus GG ameliorates Salmonella infantis-induced inflammation in a pig model via activation of the IL-22BP/IL-22/STAT3 pathway. Front. Cell Infect. Microbiol., 7: 323.

8. Wang, W. and Gänzle, M. (2019) Chapter Three - Toward rational selection criteria for selection of probiotics in pigs. In G. M. Gadd and S. Sariaslani (Eds.). Adv. Appl. Microbiol., 107: 83-112: Academic Press.

9. Abdou, A.M., Hedia, R.H., Omara, S.T., Mahmoud, M.A.E., Kandil, M.M. and Bakry, M.A. (2018) Interspecies comparison of probiotics isolated from different animals. Vet. World, 11(2): 227-230.

10. Dowarah, R., Verma, A.K., Agarwal, N., Singh, P. and Singh, B.R. (2018) Selection and characterization of probiotic lactic acid bacteria and its impact on growth, nutrient digestibility, health and antioxidant status in weaned piglets. PLoS One, 13(3): e 0192978.

11. Lertworapreecha, M., Noomee, S., Sutthimusik, S., Utarapichat, B. and Tontikapong, K. (2016) Multidrugresistant and extended-spectrum $\beta$-lactamase producing Salmonella enterica isolated from food animals in Phatthalung, Thailand. Southeast Asian J. Trop. Med. Public Health, 47(6): 1257-1269.

12. Ehrmann, M.A., Kurzak, P., Bauer, J. and Vogel, R.F. (2002) Characterization of lactobacilli towards their use as probiotic adjuncts in poultry. J. Appl. Microbiol., 92(5): 966-975.

13. O'Toole, G.A. (2011) Microtiter dish biofilm formation assay. J. Vis. Exp., 47: e2437.

14. Rahman, M., Kim, W.S., Kumura, H. and Shimazaki, K. (2008) In vitro effects of bovine lactoferrin on autoaggregation ability and surface hydrophobicity of bifidobacteria. Anaerobe, 14(2): 73-77.

15. Dias, F., Duarte, W. and Schwan, R. (2013) Evaluation of adhesive properties of presumptive probiotic Lactobacillus plantarum strains. Biosci. J., 29(1): 1678-1686.

16. Sh, M., Riaz, M.S., Hayat, H., Sarwar, S., Mehwish, M., 
Ahmad, F., Hussain, N., Shah, S., Khurshid, M., Siddiqu, M. and Shi, J. (2018) Isolation and evaluation of probiotic potential of lactic acid bacteria isolated from poultry intestine. Microbiology, 87(1): 116-126.

17. Clinical and Laboratory Standards Institute. (2017) Performance Standards for Antimicrobial Susceptibility Testing. M100-S27 Clinical and Laboratory Standards Institute, Wayne, PA.

18. Kumar, S., Stecher, G. and Tamura, K. (2018) MEGAX: Molecular evolutionary genetics analysis version 7.0 for bigger datasets. Mol. Biol. Evol., 33(7): 1870-1874.

19. Baer, A., Miller, M. and Dilger, A. (2013) Pathogens of interest to the pork industry: A review of research on interventions to assure food safety. Compr. Rev. Food Sci. Food Saf., 12(2): 183-217.

20. Rhouma, M., Beaudry, F., Thériault, W. and Letellier, A. (2016) Colistin in pig production: Chemistry, mechanism of antibacterial action, microbial resistance emergence, and one health perspectives. Front Microbiol., 7: 1789..

21. Huang, J., Zhang, W., Hu, Z., Liu, Z., Du, T., Dai, Y. and Xiong, T. (2020) Isolation, characterization and selection of potential probiotic lactic acid bacteria from feces of wild boar, native pig and commercial pig. Livest. Sci., 237: 104036.

22. Feng, Y., Qiao, L., Liu, R., Yao, H. and Gao, C. (2017) Potential probiotic properties of lactic acid bacteria isolated from the intestinal mucosa of healthy piglets. Ann. Microbiol., 67(3): 239-253.

23. Berk, P.A., Jonge, R., Zwietering, M., Abee, T. and Kieboom, J. (2005) Acid resistance variability among isolates of Salmonella enterica serovar Typhimurium DT104. J. Appl. Microbiol., 99(4): 859-866.

24. Guo, X.H., Kim, J.M., Nam, H.M., Park, S.Y. and Kim, J.M. (2010) Screening lactic acid bacteria from swine origins for multistrain probiotics based on in vitro functional properties. Anaerobe, 16(4): 321-326.

25. Ma, C., Zhang, S., Lu, J., Zhang, C., Pang, X. and Lv, J. (2019) Screening for cholesterol-lowering probiotics from lactic acid bacteria isolated from corn silage based on three hypothesized pathways. Int. J. Mol. Sci., 20(9): 2073.

26. Suiryanrayna, M.V. and Ramana, J.V. (2015) A review of the effects of dietary organic acids fed to swine. J. Anim. Sci. Biotechnol., 6(1): 45.

27. Chiang, C., Croom, J., Chuang, S., Chiou, P. and Yu, B. (2008) Development of a dynamic system simulating pig gastric digestion. Asian Aust. J. Anim., 21(10): 1522-1528.

28. Sciascia, Q., Daş, G. and Metges, C. (2016) Review: The pig as a model for humans: Effects of nutritional factors on intestinal function and health. J. Anim. Sci., 94(3): 441-452.

29. Cotter, P.D. and Hill, C., (2003) Surviving the acid test: Responses of gram-positive bacteria to low $\mathrm{pH}$. Microbiol. Mol. Biol. Rev., 67(3): 429-453.

30. Ruiz, L., Margolles, A. and Sánchez, B. (2013)Bile resistance mechanisms in Lactobacillus and Bifidobacterium. Front. Microbiol., 4: (396.

31. Botes, M., Loos, B., van Reenen, C.A. and Dicks, L.M. (2008) Adhesion of the probiotic strains Enterococcus mundtii ST4SA and Lactobacillus plantarum 423 to Caco-2 cells under conditions simulating the intestinal tract, and in the presence of antibiotics and anti-inflammatory medicaments. Arch. Microbiol., 190(5): 573-584.

32. Wang, G., Zhang, M., Zhao, J., Xia, Y., Lai, P.F.H. and Ai, L. (2018) A surface protein from Lactobacillus plantarum increases the adhesion of Lactobacillus strains to human epithelial cells. Front. Microbiol., 9: 2858.

33. Wang, R., Jiang, L., Zhang, M., Zhao, L., Hao, Y., Guo, H., Sang, Y., Zhang, H. and Ren, F. (2017) The adhesion of Lactobacillus salivarius REN to a human intestinal epithelial cell line requires S-layer proteins. Sci. Rep., 7(1): 44029.

34. Campedelli, I., Mathur, H., Salvetti, E., Clarke, S., Rea, M.C., Torriani, S., Ross, R.P., Hill, C. and O'Toole, P.W. (2019) Genus-wide assessment of antibiotic resistance in Lactobacillus spp. Appl. Environ. Microbiol., 85(1): e01738-18.

35. Zhang, S., Oh, J.H., Alexander, L.M., Ozcam, M. and van Pijkeren, J.P. (2018) D-Alanyl-D-alanine ligase as a broadhost-range counter selection marker in vancomycin-resistant Lactic acid bacteria. J. Bacteriol., 200(13): e00607-17.

36. Korhonen, J.M., Sclivagnotis, Y. and von Wright, A. (2007) Characterization of dominant cultivable lactobacilli and their antibiotic resistance profiles from faecal samples of weaning piglets. J. App. Microbiol., 103(6): 2496-2503.

37. Tille, P.M. (2014) Bailey and Scott's Diagnostic Microbiology. Elsevier, St. Louis, Missouri. p1136.

38. Adimpong, D.B., Nielsen, D.S., Sørensen, K.I., Derkx, P.M. and Jespersen, L. (2012) Genotypic characterization and safety assessment of lactic acid bacteria from indigenous African fermented food products. BMC Microbiol., 12: 75.

39. Wang, J., Zeng, Y.X., Wang, S.X., Liu, H., Zhang, D.Y., Zhang, W., Wang, Y.M. and Ji, H.F. (2018) Swine-derived probiotic Lactobacillus plantarum inhibits growth and adhesion of enterotoxigenic Escherichia coli and mediates host defense. Front. Microbiol., 9: 1364

40. Valeriano, V.D., Balolong, M.P. and Kang, D.K. (2017) Probiotic roles of Lactobacillus sp. in swine: Insights from gut microbiota. J. Appl. Microbiol., 122(3): 554-567.

41. Tannock, G.W., Fuller, R. and Pedersen, K. (1990) Lactobacillus succession in the piglet digestive tract demonstrated by plasmid profiling. Appl. Environ. Microbiol., 56(5): 1310-1316.

42. Torriani, S., Felis, G.E. and Dellaglio, F. (2001) Differentiation of Lactobacillus plantarum, L. pentosus, and $L$. paraplantarum by recA gene sequence analysis and multiplex PCR assay with recA gene-derived primers. Appl. Environ. Microbiol., 67(8): 3450-3454. 